\title{
Distribution, movements and diet of macrocrustaceans on a Scottish sandy beach with particular reference to predation on juvenile fishes
}

\author{
A. D. Ansell ${ }^{1,2, *}$, C. A. Comely ${ }^{2}$, L. Robb ${ }^{2}$ \\ ${ }^{1}$ Scottish Association for Marine Science and ${ }^{2}$ Centre for Coastal and Marine Science, Dunstaffnage Marine Laboratory, \\ PO Box 3, Oban, Argyll PA34 4AD, Scotland, UK
}

\begin{abstract}
Shrimp and crabs were sampled by beam trawl over tidal and diel cycles on a sandy beach on the west coast of Scotland in June and August. There were significant positive relationships between depth $(0$ to $5 \mathrm{~m})$ and numbers of individuals and numbers of species caught. More species and individuals were caught at night than by day, but there was no evidence for the existence of distinct 'day' and 'night' communities. Differences in species composition and numbers caught reflected differences in the migratory and burying behaviour of individual species. The macrocrustaceans found on this beach are omnivorous predators feeding on a wide range of prey species. Predation by them is one cause of mortality for the populations of juvenile fishes on the beach. Two species, the shrimp Crangon crangon and the shore crab Carcinus maenas, account for most of such predation by macrocrustaceans, which affects both round and flatfish juveniles in varying proportions at different times. In particular, the intensity of predation was generally greatest at night for both species.
\end{abstract}

KEY WORDS: Crabs - Shrimps · Sandy beach - Diel movements - Tidal movements - Diet - Fish predation Crangoncrangon. Carcinus maenas

\section{INTRODUCTION}

Aspects of the animal communities of intertidal and shallow sublittoral sand communities have been extensively studied in many parts of the world. The benthic infauna, the small motile epifauna and the pelagic and demersal fish populations have received much attention (Brown \& McLachlan 1991). In contrast, sandy beach macrocrustacean populations have received less attention, and studies have generally concentrated on individual species rather than the complete assemblage, although several authors have examined the impact of macrocrustacean predators on the infaunal benthos (Hall et al. 1990 and references therein).

Sandy beaches act as important nursery grounds for juvenile fishes, and particularly, in temperate regions,

•E-mail: ala@wpo.nerc.ac.uk for juvenile flatfishes (Edwards \& Steele 1968, Lockwood 1974, Gibson et al. 1993 among others). Juvenile flatfishes recruit to the beach populations in the spring and early summer, reaching a post-settlement peak of abundance, followed by a decline in numbers. Predation is usually considered to be a major contributing factor to this decline (Beverton \& Iles 1992), but until recently there were few studies that established the identity of the main predators.

This paper presents results from a study that was designed to investigate the distribution and diet of potential predators on juvenile fishes among the fish and macrocrustacean populations on a Scottish sandy beach, and to examine changes in their distribution and diet over tidal and diel cycles. The distribution and movements of the fishes, both predator and prey species, and the role of the larger fishes as predators on juveniles have been described in earlier publications 
(Gibson \& Robb 1996, Gibson et al. 1996). Here we present comparable data for the macrocrustacean populations. Specific objectives of this aspect of the study were to determine (1) whether the species composition and/or relative abundance of members of the macrocrustacean assemblage differ between night and day; (2) how the species are distributed with depth, and how the depth distributions are affected by the state of the tide, the time of day, and the time of year; (3) what is the overall composition of the diets of different species, and whether juvenile fishes are a significant component of those diets; and (4) whether feeding intensity changes between day and night, or with depth. This investigation forms part of a wider study of predatorprey interactions in the ecology of sandy beach fish populations (Ansell \& Gibson 1990, Gibson et al. 1993, 1996, 1998, Burrows et al. 1994).

\section{MATERIALS AND METHODS}

Study area. The study area, Tralee Beach, is situated in Ardmucknish Bay in the Firth of Lorn on the west coast of Scotland $\left(56^{\circ} 29^{\prime} \mathrm{N}, 5^{\circ} 25^{\prime} \mathrm{W}\right.$ ) (see Gibson et al. 1993, 1996, Gibson \& Robb 1996 for detailed descriptions). This beach supports a rich fish community, of which juvenile flatfishes are an important component, and a varied macrocrustacean community (Gibson et al. 1993).

Field methods. The macrocrustaceans for study were collected during a programme of sampling designed to study both fish and macrocrustacean predation on young fishes at times during the night when predation was considered to be most likely (based on literature references to the activity patterns of potential predators), and to compare these samples with others taken during the day. The sampling regime and rationale and the methods used have been described by Gibson et al. (1996) and Gibson \& Robb (1996). For this study, samples were collected on 4 dates in June and August 1990, but for logistical reasons macrocrustaceans were exam- ined for only 3 of the 4 groups of samples collectedthose of June 14, June 20 and August 6. On the first of these occasions, high water, and on the other 2 occasions, low water, occurred during the night. On each occasion, 5 sets of samples were taken at set times relative to sunset and sunrise, namely: $3 \mathrm{~h}$ before sunset (SS - 3), 1 h after sunset ( $\mathrm{SS}+1$ ), midway through the night (MSSSR), at sunrise (SR), and $3 \mathrm{~h}$ after sunrise $(S R+3)$. Seven samples were taken in each set: 5 using a $2 \mathrm{~m}$ beam trawl towed for approximately $5 \mathrm{~min}$ parallel to the shore in depths of $0.5,1,2,3$, and $4 \mathrm{~m}$, one using a $3 \mathrm{~m}$ beam trawl hauled parallel to shore at $5 \mathrm{~m}$ depth, and 1 using a $36 \times 1.8 \mathrm{~m}$ net beach seine set parallel to and approximately $50 \mathrm{~m}$ from the shore at a depth of 1 to $1.5 \mathrm{~m}$. Only the trawl samples have been used for study of the macrocrustaceans, which, except for the shrimp Crangon crangon, were not well represented in the seine samples.

The $2 \mathrm{~m}$ beam trawl used was fitted with 3 tickler chains and had a stretched mesh of $15 \mathrm{~mm}$ in the main body of the net and of $3 \mathrm{~mm}$ in the cod-end. At $0.5 \mathrm{~m}$, the trawl was hauled by hand by 2 persons. At 1, 2, 3 and $4 \mathrm{~m}$, the trawl was hauled by boat, maintaining depth by frequent use of a plumb line. At $5 \mathrm{~m}$, the traw was towed by a larger vessel which also served as a floating laboratory for sorting and preservation of specimens. Hauls were approximately standardised by towing for a specified time and at a constant speed as judged from the engine note, by markers on the shore during daylight, or by counting paces. The distance trawled in each case was measured by means of a cyclometer attached to the trawl. Where clogging by weed or other mechanical failure prevented measurement, the distance trawled was taken as the mean of the distances measured in other similar hauls. An entire series of trawls from $5 \mathrm{~m}$ to $0.5 \mathrm{~m}$ usually took approximately $1 \mathrm{~h}$ to complete, but time constraints in the face of changing light and tide conditions did not allow replicate hauls to be taken. The actual dates and times of sampling are given in Table 1, together with the state of the tide.

Table 1. Details of sampling dates (1990) and times (British Summer Time) during the investigation. Also shown are the predicted times of high water (HW), and low water (LW); high water height (in m above Chart Datum); and in parentheses, as decimal hours, the sampling times before $(-)$ or after $(+)$ high water

\begin{tabular}{|c|c|c|c|c|c|c|c|c|}
\hline Date & $S S-3$ & $\mathrm{SS}+1$ & $\begin{array}{l}\text { nple time } \\
\text { MSSSR }\end{array}$ & $\mathrm{SR}$ & $\mathrm{SR}+3$ & $\begin{array}{l}\text { Time of } \\
\text { HW (h) }\end{array}$ & $\begin{array}{l}\text { Time of } \\
\text { LW }(h)\end{array}$ & $\begin{array}{l}\text { Height } \\
\text { of } \mathrm{HW}(\mathrm{m})\end{array}$ \\
\hline 14 to 15 Jun & $\begin{array}{c}19: 03 \\
(-3.57)\end{array}$ & $\begin{array}{c}23: 03 \\
(+0.43)\end{array}$ & $\begin{array}{c}01: 17 \\
(+2.67)\end{array}$ & $\begin{array}{l}04: 31 \\
(+5.9)\end{array}$ & $\begin{array}{c}07.31 \\
(-3.27)\end{array}$ & $\begin{array}{l}22: 37 \\
10: 47\end{array}$ & $\begin{array}{l}16: 28 \\
05: 11\end{array}$ & $\begin{array}{l}3.4 \\
3.0\end{array}$ \\
\hline 20 to 21 Jun & $\begin{array}{c}19: 06 \\
(+2.6)\end{array}$ & $\begin{array}{c}23: 06 \\
(-6.08)\end{array}$ & $\begin{array}{c}01: 18 \\
(-3.88)\end{array}$ & $\begin{array}{c}04: 31 \\
(-0.67)\end{array}$ & $\begin{array}{c}07.31 \\
(+2.33)\end{array}$ & $\begin{array}{l}16: 30 \\
05: 11\end{array}$ & $\begin{array}{l}22: 48 \\
11: 14\end{array}$ & $\begin{array}{l}3.4 \\
3.6\end{array}$ \\
\hline 6 to 7 Aug & $\begin{array}{c}18: 15 \\
(-0.71)\end{array}$ & $\begin{array}{c}22: 15 \\
(+3.26)\end{array}$ & $\begin{array}{c}01: 23 \\
(-5.92)\end{array}$ & $\begin{array}{c}05.31 \\
(-1.78)\end{array}$ & $\begin{array}{c}08.31 \\
(+1.21)\end{array}$ & $\begin{array}{l}18: 58 \\
07: 18\end{array}$ & $\begin{array}{l}01: 09 \\
13: 24\end{array}$ & $\begin{array}{l}3.9 \\
3.7\end{array}$ \\
\hline
\end{tabular}


To prevent regurgitation of the gut contents during preservation, the macrocrustaceans were killed by immersion in boiling water before being preserved in $8 \%$ formalin. All crabs were preserved, but only shrimps of $30 \mathrm{~mm}$ or more in total length were examined since below that size shrimps are unlikely to capture newly settled flatfish (van der Veer \& Bergman 1987).

Laboratory methods. The macrocrustaceans collected in each haul were counted and measured. The foregut (gastric mill) was removed from each and fullness (SF) estimated on a subjective scale of 0 to 5 , where $0=$ empty, $1=$ remnants only, $2=\sim 25 \%$ full, $3=$ $-50 \%$ full, $4=-75 \%$ full and $5=-100 \%$ full. Prey items were separated under a binocular microscope and identified to the lowest taxonomic category possible.

To estimate the percentage of the volume of the total contents $(\% V)$ accounted for by each individual item, the smallest item was allocated a value of 1 , and the volume of all other items related to it, the total being summed and the individual items then expressed as a percentage of the summed total. The volumetric importance of each food type in the diet was then assessed by means of a volume index for each individual calculated by multiplying the foregut fullness (SF) by the percentage volume of each category $(\% \mathrm{~V})$. Values for this index can range from 0 representing an empty foregut to 500 for a full foregut $(\mathrm{SF}=5)$ containing only 1 category of food $(\% V=100)$.

Data analysis. Abundance of the macrocrustaceans caught was measured as the number per $100 \mathrm{~m}^{2}$ trawled. This measure does not represent true abundance because the efficiency of the trawl is unknown. For juvenile plaice Pleuronectes platessa, efficiency has been estimated as of the order of 30 to $40 \%$ or less (Kuipers 1975, Rogers \& Lockwood 1989, Wennhage et al. 1997), and similar values apply to Crangon crangon (Wennhage et al. 1997).

Two questions were asked about the macrocrustacean population and variations in its distribution. First, does the structure of the macrocrustacean community, as defined by the overall numbers of individuals and species, change spatially and temporally? Second, how do the abundance and distribution of individual species change spatially and temporally?

To answer these questions, 2 approaches were used. First, the similarity between the species composition of the combined catches on each sample date was assessed by calculating percent similarity (Krebs 1989). Percent similarity is given by:

$$
P=\sum \text { minimum }\left(p_{1}, p_{2 i}\right)
$$

where $p_{1 i}=$ percentage of species $i$ in sample 1 and $p_{21}$ $=$ percentage of species $i$ in sample 2 . Second, analysis of variance (GLM procedure, SAS Institute Inc. 1990) was used to test the significance of changes in the total number of species, the total number of individuals, and the numbers of individuals of the most abundant species. Two alternative designs were used in the same way as was employed for fishes from the same study (Gibson et al. 1996). In the first, variance due to the 3 crossed factors of depth, time of day, and sampling date and their 2-way interactions was tested over the residual variation (Model 1 in Table 4). The 3-way interaction was included as part of the error term. In the second, the state of the tide at the time of sampling was included as the time relative to the closest high water, from low water 6 h before high water to low water $6 \mathrm{~h}$ after high water. Cosines, and sines, of the angular equivalent of the state of the cycle $(2 \pi \times$ [time relative to predicted time of high water $/ 12.43 \mathrm{~h}$ ) were included as covariants in the analysis (Model 2 in Table 4). The cosines reflect changes from low water to high water, while sines reflect differences between ebb and flood tide. Regression equations resulting from this analysis were used to predict values for each state of the tide. The $\log _{10}$ of total numbers of species, and numbers of individuals, were used in the analyses of variance. Abundances of individual species were transformed using $\log _{10}(1+n)$ before analysis.

For most analysis of the data on diet, the main items found in the foreguts, including sand, were grouped into 26 major categories (e.g. Crustacea, which includes all materials identifiably as from a crustacean source, including chitin) (see Table 5). The diets of those macrocrustacean species that were collected in sufficient numbers were compared by means of the percentage frequency of occurrence for each food category, and of a mean volumetric index. The percentage occurrence was calculated as a percentage of the total number of foreguts examined that contained food. The mean volumetric index was calculated as the percentage contribution of each constituent to the sum of individual volume indices. Correlation between these 2 methods was examined using Spearman rank correlation coefficients. Levins' measure of niche breadth (Krebs 1989) was calculated for each species together with estimates of percentage overlap in the diet between pairs of species (Krebs 1989), using the volume index data.

Three questions were asked concerning possible variations in feeding intensity. First, does the proportion of feeding individuals in the population change spatially and temporally? Second, does the intensity of feeding change? Third, does the proportion of individuals feeding on juvenile fishes change? Questions 1 and 3 were addressed by examining respectively the proportion of the population that had empty foreguts and the proportion with fish remains in the foregut at different depths and at different sampling times. An 
Table 2. Species composition of the total catches as percentages of mean numbers per $100 \mathrm{~m}^{2}$ Species nomenclature follows Hayward \& Ryland (1990)

\begin{tabular}{|c|c|c|c|c|c|c|c|}
\hline \multirow{2}{*}{ Family } & \multirow[t]{2}{*}{ Species } & \multicolumn{2}{|c|}{14 Jun } & \multicolumn{2}{|l|}{$20 \mathrm{Jun}$} & \multirow{2}{*}{$\begin{array}{c}6 \text { Aug } \\
\text { No. per } 100 \mathrm{~m}^{2}\end{array}$} & \multirow[b]{2}{*}{$\%$} \\
\hline & & No. per $100 \mathrm{~m}^{2}$ & $\%$ & No. per $100 \mathrm{~m}^{2}$ & $\%$ & & \\
\hline Crangonidae & Crangon crangon & 656.46 & 87.46 & 330.20 & 78.36 & 117.08 & 68.39 \\
\hline Paguridae & Pagurus bernhardus & 5.36 & 0.71 & 9.30 & 2.21 & 3.27 & 1.91 \\
\hline \multirow[t]{2}{*}{ Majidae } & Hyas araneus & 0.25 & 0.03 & 0.17 & 0.04 & 0.00 & 0.00 \\
\hline & Macropodia rostrata & 0.00 & 0.00 & 0.00 & 0.00 & 0.18 & 0.10 \\
\hline Corystidae & Corystes cassivelaunus & 0.59 & 0.08 & 1.25 & 0.30 & 0.00 & 0.00 \\
\hline Cancridae & Cancer pagurus & 0.17 & 0.02 & 0.00 & 0.00 & 0.00 & 0.00 \\
\hline \multirow[t]{3}{*}{ Portunidae } & Liocarcinus depurator & 7.97 & 1.06 & 5.91 & 1.40 & 4.25 & 2.48 \\
\hline & Liocarcinus holsatus & 19.61 & 2.61 & 18.88 & 4.48 & 12.09 & 7.06 \\
\hline & Carcinus maenas & 60.07 & 8.00 & .55 .67 & 13.21 & 34.34 & 20.06 \\
\hline
\end{tabular}

approach was used which was similar to that employed to test the significance of changes in the numbers of individuals and species but using the maximum-likelihood method of the CATMOD procedure (SAS Institute Inc. 1990). CATMOD computes test statistics, known as Wald statistics, for the specified statistical model, which are approximately distributed as chisquare when the null hypothesis is true. Interactions between Depth, Time of Day (TOD) and sampling Date could not be tested, however, because of the presence of zero values. Question 2 was examined using an analysis of the distribution of fullness scores for each sample period (Kruskal-Wallis test). All statistical tests were done using the SAS statistical package (SAS Institute Inc. 1990).

\section{RESULTS}

\section{Species composition of the catches}

Only 9 species of macrocrustaceans were caught during the study (Table 2). The catches were dominated by only 2 species, shrimp Crangon crangon and shore crabs Carcinus maenas, but 3 other species, the swimming crabs Liocarcinus holsatus and $L$. depurator and the hermit crab Pagurus bernhardus, occurred relatively frequently. These 5 species together aiways made up $>90 \%$ of the catch. The species composition

Table 3. Percentage similarities between dates in the species composition of catches. Values above the diagonal are for crustaceans; those below the diagonal are for fishes in the same catches from Gibson et al. (1996)

\begin{tabular}{|cccc|}
\hline & 14 Jun & 20 Jun & 6 A.ug \\
\hline 14 Jun & - & 91 & 81 \\
20 Jun & 92 & - & 89 \\
6 Aug & 62 & 64 & - \\
\hline
\end{tabular}

of the catches made at different times of day on each date showed relatively little variation, but in general, similarity was greatest between adjacent times. None of the species was caught exclusively during the day or at night. The species composition of the combined catches was very similar among dates (Table 3) with the 2 June samples more closely similar to each other than to the August sample.

\section{Depth, diel, tidal and seasonal influences on catch composition}

Total number of species and individuals

The average number of species caught in the trawls increased from approximately 2 in $0.5 \mathrm{~m}$ of water to around 5 in $5 \mathrm{~m}$. The total number of individuals was higher at $1 \mathrm{~m}$ depth than at $0.5 \mathrm{~m}$, but then declined markedly to minimum values at 4 and $5 \mathrm{~m}$ depths (Fig. 1A). Catches at night contained more individuals of more species than those taken in daytime, with maximum numbers of individuals and species caught at MSSSR (Fig. 1B). The mean number of individuals caught showed no significant effect of the state of the tide, but the tidal effect on the number of species caught was significant (Fig. 1C) with higher numbers of species being caught at low water than at high water (Table 4, significant Depth, Time of Day and Cosine effects). For numbers of species, depth of capture accounted for the largest percentage $(34.5 \%)$ of the total variation. For individuals, the greatest percentage $(30.9 \%)$ of the variation was accounted for by date of capture (Table 4). The numbers of individuals in the trawls declined between June and August, but the number of species caught was not affected significantly (Fig. 1D, Table 4, significant Date effect).

Both the numbers of individuals and the number of species showed significant Date by Time of Day interactions, accounting for $5.8 \%$ and $15.1 \%$ of the total 
variation respectively. Although the mean number of individuals caught was greatest at MSSSR on all the dates, there were considerable differences between dates in the pattern of catches before sunset (SS - 3) and after sunrise $(S R+3)$. The number of species caught showed least variation at SS -3 and MSSSR and greatest variation at $\mathrm{SS}+1$ and $\mathrm{SR}+3$ (Fig. 2). Depth distributions showed no significant variation among sample dates, nor did depth distributions show significant interaction with Time of Day, but both these interactions were significant for individuals (Table 4 , Date by Depth and Time of Day by Depth interactions), the latter accounting for $21.0 \%$ of total variation. Overall, Model 1 accounted for 83.0 and $87.7 \%$ of the variance in numbers of species and numbers of individuals respectively. Model 2 accounted for a smaller proportion of the variation in each case (Table 4 ).
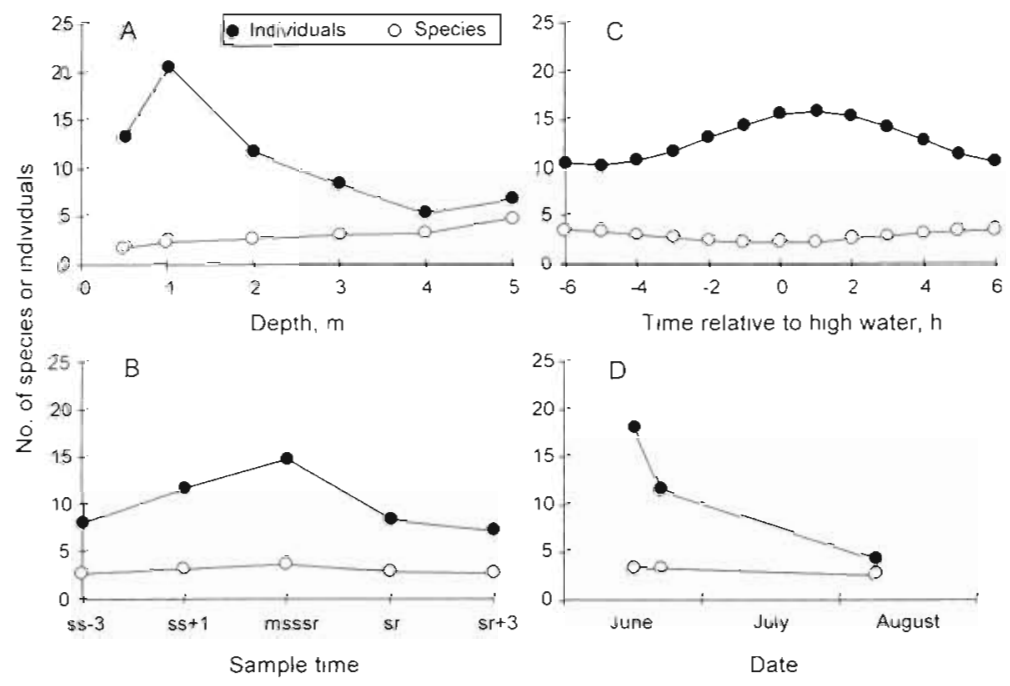

Fig. 1. Variations in geometric mean number of species and individuals for all catches combined. (A) Variation with depth. (B) Variation with sample time. (C) Variation with time of tide; values plotted are those predicted by the regressions - see text for further details. (D) Variation with date. SS - 3: $3 \mathrm{~h}$ before sunset, SS $+1.1 \mathrm{~h}$ after sunset, MSSSR: midway through the night, $S R$ : sunrise, $S R+3: 3 \mathrm{~h}$ after sunrise

Table 4. Significance associated with probabilities of $F$-ratios from analyses of variance on summary statistics of catches and percentage of total variance accounted for by each variable. For details of the 2 ANOVA models see 'Materials and methods' Numbers of individuals and of species were transformed to $\log _{10}$ before analysis. Numbers of individual crustaceans of each species per $100 \mathrm{~m}^{2}$ were transformed to $\log _{10}(n+1)$ before analysis. C cra: Crangon crangon; $C$ mae: Carcinus maenas; $L$ hol: Liocarcinus hosatus; $L$ dep:

Liocarcinus depuratori P ber: Pagurus bernhardus. Significance: ${ }^{\cdots} p<0.001, \cdots 0.001<p<0.01, \cdot 0.01<p<0.05$, ns: $p>0.05$

\begin{tabular}{|c|c|c|c|c|c|c|c|c|}
\hline Source & $\mathrm{df}$ & $\begin{array}{l}\text { No. of } \\
\text { species }\end{array}$ & $\begin{array}{c}\text { No. of } \\
\text { individuals }\end{array}$ & C cra & Cmae & L hol & $L$ dep & $P$ bes \\
\hline \multicolumn{9}{|l|}{ ANOVA } \\
\hline \multicolumn{9}{|l|}{ Model 1} \\
\hline Depth & 5 & $\cdots$ & $\cdots$ & $\cdots$ & $\cdots$ & ns & $\cdots$ & $\cdots$ \\
\hline Time of day (TOD) & 4 & $\cdots$ & $\cdots$ & ns & $\cdots$ & $\cdot \cdot$ & ns & ns \\
\hline Date & 2 & . & ... & $\cdots$ & . & ns & ns & $\cdot$ \\
\hline TOD by Depth & 20 & ns & .. & ns & $\cdot$ & ns & ns & ns \\
\hline Date by Depth & 10 & ns & - & ns & ns & ns & ns & $\cdot$ \\
\hline Date by TOD & 8 & $\cdots$ & $\cdot \cdot$ & $\cdot \cdot$ & ns & ns & ns & $\cdot$ \\
\hline \multicolumn{9}{|l|}{ Model 2} \\
\hline Depth & 5 & $\cdots$ & $\cdots$ & $\cdots$ & $\cdots$ & ns & $\cdots$ & $\cdots$ \\
\hline TOD & 4 & ns & • & ns & ... & $\cdots$ & ns & ns \\
\hline Date & 2 & ns & $\cdots$ & $\cdots$ & • & ns & ns & .. \\
\hline Cosine (time relative to high water) & 1 & $\cdots$ & ns & .. & $\cdot$ & ns & ns & $\cdot$ \\
\hline Sine (time relative to high water) & 1 & ns & ns & ns & ns & ns & ns & ns \\
\hline \multicolumn{9}{|l|}{ Percentage of total variance } \\
\hline \multicolumn{9}{|l|}{ Model 1} \\
\hline Depth & 5 & 34.5 & 17.2 & 36.7 & 25.2 & 6.6 & 54.6 & 52.1 \\
\hline TOD & 4 & 7.2 & 7.6 & 1.6 & 23.3 & 27.7 & 3.5 & 3.3 \\
\hline Date & 2 & 7.0 & 30.9 & 21.7 & 7.1 & 2.1 & 1.9 & 6.8 \\
\hline TOD by Depth & 20 & 15.3 & 21.0 & 14.2 & 18.8 & 16.2 & 11.1 & 12.2 \\
\hline Date by Depth & 10 & 4.0 & 5.3 & 3.6 & 4.0 & 9.6 & 2.8 & 7.6 \\
\hline Date by TOD & 8 & 15.1 & 5.8 & 8.2 & 6.6 & 9.6 & 3.2 & 5.9 \\
\hline Model 1 total & 49 & 83.0 & 87.7 & 86.1 & 84.9 & 71.7 & 72.1 & 87.9 \\
\hline \multicolumn{9}{|l|}{ Model 2} \\
\hline Depth & 5 & 34.5 & 17.2 & 36.7 & 25.2 & 6.6 & 54.6 & 52.1 \\
\hline TOD & 4 & 7.2 & 7.6 & 1.6 & 23.3 & 27.7 & 3.5 & 3.3 \\
\hline Date & 2 & 7.0 & 30.9 & 21.7 & 7.1 & 2.1 & 1.9 & 6.8 \\
\hline Cosine (time relative to high water) & 1 & 8.6 & 1.3 & 4.7 & 3.3 & 0.0 & 1.6 & 2.7 \\
\hline Sine (time relative to high water) & 1 & 0.1 & 0.3 & 1.0 & 1.8 & 0.6 & 0.2 & 0.4 \\
\hline Model 2 total & 13 & 57.3 & 57.6 & 65.8 & 60.6 & 36.9 & 61.8 & 65.2 \\
\hline
\end{tabular}



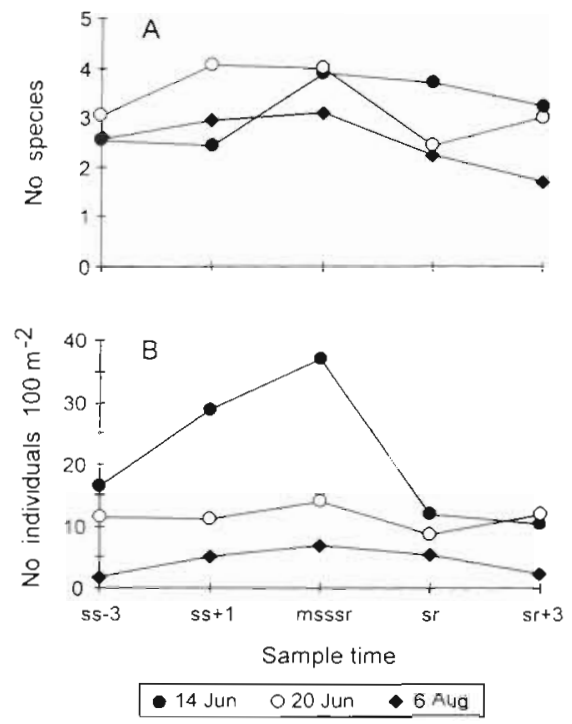

Fig. 2. Diel variation in geometric mean numbers of $(A)$ species and (B) individuals for all catches combined. Abbreviations as in Fig. 1

\section{Abundance of dominant species}

The pattern of change in the overall catches is the resultant of the changing distributions of the dominant species. All of the species considered except Liocarcinus holsatus, showed significant changes in abundance with depth, accounting for between 25.2 (Carcinus maenas) and $54.6 \%$ ( $L$. depurator $)$ of total variation. Crangon crangon was most abundant in shallow water, its numbers declining progressively at depths greater than $1 \mathrm{~m}$. C. maenas showed an opposite trend, its numbers increasing progressively with depth. L. depurator and Pagurus bernhardus were caught almost exclusively only in the $5 \mathrm{~m}$ depth trawls. $l$. holsatus was most abundant at intermediate depths but its distribution was more even with depth than the other species, and differences were not significant (Fig. 3A, Table 4).

Carcinus maenas and Liocarcinus holsatus both showed significant effects of Time of Day, accounting for 23.3 and $27.7 \%$ respectively of total variation (Table 4). Both were more abundant in catches at night than by day (Fig. 3B). Crangon crangon, L. depurator and Pagurus bernhardus showed no significant change in numbers with time. C. crangon, $C$. maenas and $P$. bernhardus showed significant changes in distribution with the state of the tide (Fig. 3C, Table 4, effect of Cosine), although this factor accounted for only a relatively small percentage of total variation (Table 4). C. crangon was more abundant at high water while the latter 2 species were less abundant at high water than at low water There was a significant decline in $C$. crangon and $C$. maenas abundances between June and August (Fig. 3D).

Not all these trends were consistent among sampling occasions, as indicated by the significant interactions between the main variables (Table 4). For Crangon crangon and Pagurus bernhardus the decline in numbers from June to August was not consistent at all sampling times, leading to significant Date by Time of Day interaction (Fig. 4A, B). Carcinus maenas and $P$. bernhardus showed significant Time of Day by Depth, and Date by Depth interactions respectively (Fig. 4C, D, Table 4). For individual species, Model 1 accounted for between 71.7 (Liocarcinus holsatus) and $87.9 \%$ (P. bernhardus) of total variation, and Model 2 between 36.9 and $65.8 \%$ (Table 4 ).

\section{Overall diet analysis}

The overall diets of the 5 most abundant species of macrocrustaceans, based on analysis of all the individuals examined, are summarised in Table 5 (as percentage occurrence) and Table 6 (based on volume index). Spearman rank correlation coefficients show that the percentage frequency of occurrence of each category of food item and the volume
Fig. 3. Variations in geometric mean numbers of common crustacean species in catches. (A) Variation with depth. (B) Variation with sample time. (C) Variation with time of tide; values plotted are those predicted by the regressions - see text for further details. (D) Variation with date. Note different scale for Crangon crangon numbers. Abbreviations as In Fig. 1 and Table 4 
index of that item in the foreguts were strongly related for Crangon crangon, Carcinus maenas and Pagurus bernhardus but not for the Liocarcinus species (Table 6).

Levins' standardized measure of niche breadth ranged from 0.09 for Pagurus bernhardus to 0.31 for Crangon crangon when sand was included as a diet item, and from 0.06 to 0.41 when sand was excluded (Table 6). Values for the percentage overlap in diet between pairs of species ranged from 22.5 ( $P$. bernhardus and Liocarcinus depurator) to 67.4 ( $L$. holsatus and $L$. depurator) (Table 7). The diets of the 3 species of portunid crabs generally showed the highest degree of overlap; that of $C$. crangon showed a slightly lower degree of overlap with all the other species examined; while the diets of $P$. bernhardus and of the portunid crabs showed least overlap. The diet of $P$. bernhardus, though, had the greatest proportion of unidentified miscellaneous material. These relationships were similar whether or not sand was included as a component of the diet (Table 7).

All the species examined showed a broad spectrum of diet items. Crustaceans were among the most important components for both shrimps and crabs, but often represented predominantly of chitin only. Identifiable remains included Crangon crangon, juveniles of the crab Corystes cassivelaunus, the amphipods Bathyporeia sp. and Pontocrates sp., and the isopod Eurydice sp. Smaller species of crustaceans, such as copepods, ostracods, and the cyprid larvae of barnacles, were found consistently in shrimp and crab foreguts. In crabs these were probably taken in with larger food items; one Carcinus maenas foregut, for example, contained a complete juvenile Myxocephalus scorpius which had copepods, ostracods and an amphipod in its stomach, and most occurrences of such small crustaceans were in crustacean foreguts that also contained fish remains. C. crangon are probably able to prey directly on such small animals and here there was no relationship with the presence of fish remains.

Polychaetes and filamentous algae were the next most important food categories for Crangon crangon, the former including the terebellid Lanice conchilega and the arenicolid Arenicola marina, both of which are important members of the shallow water infauna (Gregory 1988). During the June 14 sampling it was observed that heteronereis stages of nereid polychaetes (probably Nereis longissima) were swarming in the bay and these were found in a number of shrimp foreguts taken at that time. Remains of nephtyd, spionid and polynoid (harmothoid) polychaetes also appeared consistently in the foreguts of shrimps. Polychaetes were relatively less important in the diet of the portunid crabs, but included the same taxa. No polychaete material was found in the foreguts of Pagurus bernhardus.

Molluscs were generally less important components of the diets. In shrimps, identifiable remains included the bivalves Cardium sp. and Tellina sp. and the gastropod Retusa obtusa, all $<5 \mathrm{~mm}$ in length. In crabs, the molluscs identified were predominantly bivalves, with Tellina sp. being the most abundant.

Filamentous and thallic algae, in varying proportions and abundance, were found in both shrimps and crabs. Individual Carcinus maenas had sometimes taken large amounts of thallic algae, particularly Laminaria $\mathrm{sp}$, and this accounted for the greater importance of this item in the diet when compared with Crangon crangon. Sand was also found in many of the foreguts examined and contributed significantly to the total volume, especially in C. crangon.

Only Crangon crangon and Carcinus maenas were sufficiently numerous to allow temporal and spatial changes in diet composition and feeding intensity to be investigated in detail. There was no evidence of any consistent trend or change in the major constituents of the diet of either species with time or depth of sampling. The contribution of the different major con- 
Table 5. Diets of the common species of crustacean in catches as percentage frequency of occurrence in the foreguts of each species. The total number of foreguts examined and the number of foreguts with food are also given. Species abbreviations as in Table 4

\begin{tabular}{|lrrrrr|}
\hline & Ccra & C mae & L hol & L dep & P ber \\
\hline No. examined & 2279 & 582 & 212 & 71 & 72 \\
No. with food & 1245 & 498 & 169 & 48 & 67 \\
Polychaeta & & & & & \\
$\quad$ Polynoidae & 2.01 & 0.00 & 2.37 & 0.00 & 0.00 \\
Phyllodocidae & 2.97 & 0.20 & 0.00 & 0.00 & 0.00 \\
Syllidae & 1.45 & 0.20 & 0.59 & 2.08 & 0.00 \\
Nereidae & 12.29 & 9.04 & 7.69 & 16.67 & 0.00 \\
Nephtydae & 0.80 & 1.41 & 0.00 & 4.17 & 0.00 \\
Spionidae & 1.37 & 0.40 & 0.59 & 0.00 & 0.00 \\
Arenicolidae & 0.24 & 0.20 & 0.59 & 0.00 & 0.00 \\
Terebellidae & 2.89 & 3.01 & 5.33 & 6.25 & 0.00 \\
Ident. Polychaeta & 0.24 & 0.40 & 0.59 & 2.08 & 0.00 \\
Unident. Polychaeta & 2.17 & 1.41 & 4.73 & 0.00 & 0.00 \\
Insecta & 1.53 & 0.20 & 0.59 & 0.00 & 0.00 \\
Crustacea & & & & & \\
Isopoda & 6.75 & 0.20 & 0.00 & 0.00 & 0.00 \\
Amphipoda & 12.77 & 2.61 & 4.73 & 2.08 & 1.49 \\
Mysidacea & 1.29 & 0.60 & 0.00 & 0.00 & 0.00 \\
Decapoda & 4.66 & 12.05 & 12.43 & 14.58 & 1.49 \\
Ident. Crustacea & 6.75 & 6.83 & 5.92 & 2.08 & 2.99 \\
Unident. Crustacea & 30.04 & 24.30 & 43.20 & 35.42 & 32.84 \\
Mollusca & & & & & \\
$\quad$ Gastropoda & 1.29 & 0.00 & 0.00 & 0.00 & 0.00 \\
Bivalvia & 4.66 & 30.72 & 3.55 & 20.83 & 8.96 \\
Ident. M.llusca & 0.24 & 6.43 & 1.18 & 10.42 & 0.00 \\
Echinodermata & 0.00 & 0.00 & 0.59 & 2.08 & 0.00 \\
Teleostei & 6.02 & 54.82 & 27.81 & 8.33 & 4.48 \\
Algae (filamentous) & 33.09 & 16.47 & 17.16 & 8.33 & 31.34 \\
Algae (thallic) & 4.98 & 9.84 & 2.96 & 2.08 & 7.46 \\
Sand & 72.53 & 45.38 & 54.44 & 31.25 & 83.58 \\
Miscellaneous & 15.18 & 14.46 & 24.85 & 14.58 & 79.10 \\
Totals & & & & & \\
Polychaeta & 26.43 & 16.27 & 22.49 & 31.25 & 0.00 \\
Crustacea & 62.25 & 46.59 & 66.27 & 54.17 & 38.81 \\
Mollusca & 6.18 & 37.15 & 4.73 & 31.25 & 8.96 \\
\hline
\end{tabular}

stituents was also similar on all 3 sampling dates, although there were minor differences in the importance of individual components. Of the individual prey items identified, Eurydice sp. (probably E. pulchra) were

Table 7 . Values of percentage overlap between the diets of the common crustaceans in catches. Values where sand is included as a diet item are given above the diagonal and those where sand is excluded below it. Species abbreviations as in Table 4

\begin{tabular}{|lccccc|}
\hline & C cra & C mae & L hol & L dep & P ber \\
\hline C cra & - & 53.5 & 48.1 & 43.7 & 53.6 \\
C mae & 51.1 & - & 48.0 & 54.2 & 29.1 \\
L hol & 58.8 & 52.8 & - & 67.4 & 28.2 \\
L dep & 52.7 & 58.3 & 67.5 & - & 22.5 \\
$P$ ber & 40.3 & 22.1 & 37.1 & 25.0 & - \\
\hline
\end{tabular}

Table 6. Diets of the common species of crustaceans in catches as \% volume based on the volume index - see text for further details. Values of Levins' standardized index of diet breadth based on the volume percentages (a) with sand included and (b) without sand and Spearman rank correlation coefficients between percentage occurrence and \% volume are also given. Species abbreviations as in Table 4

\begin{tabular}{|c|c|c|c|c|c|}
\hline & C cra & Cmae & $L$ hol & $L$ dep & $P$ ber \\
\hline No. examined & 2279 & 582 & 212 & 71 & 72 \\
\hline No. with food & 1245 & 498 & 169 & 48 & 67 \\
\hline \multicolumn{6}{|l|}{ Polychaeta } \\
\hline Polynoidae & 0.69 & 0.00 & 1.07 & 0.00 & 0.00 \\
\hline Phyllodocidae & 1.33 & 0.03 & 0.00 & 0.00 & 0.00 \\
\hline Syllidae & 0.33 & 0.00 & 0.1 .1 & 0.64 & 0.00 \\
\hline Nereidae & 9.60 & 8.89 & 10.64 & 24.25 & 0.00 \\
\hline Nephtydae & 0.36 & 0.93 & 0.00 & 2.47 & 0.00 \\
\hline Spionidae & 0.97 & 0.23 & 0.05 & 0.00 & 0.00 \\
\hline Arenicolidae & 0.24 & 0.24 & 0.77 & 0.00 & 0.00 \\
\hline Terebellidae & 1.26 & 2.49 & 3.94 & 6.82 & 0.00 \\
\hline Ident. Polychaeta & 0.12 & 0.12 & 0.39 & 0.86 & 0.00 \\
\hline Unident. Polychaeta & 1.13 & 0.72 & 0.65 & 0.00 & 0.00 \\
\hline Insecta & 0.52 & 0.00 & 0.92 & 0.00 & 0.00 \\
\hline \multicolumn{6}{|l|}{ Crustacea } \\
\hline Isopoda & 5.60 & 0.14 & 0.00 & 0.00 & 0.00 \\
\hline Amphipoda & 7.89 & 0.99 & 2.77 & 4.29 & 0.03 \\
\hline Mysidacea & 1.68 & 0.67 & 0.00 & 0.00 & 0.00 \\
\hline Decapoda & 3.51 & 9.46 & 13.46 & 12.04 & 0.07 \\
\hline Ident. Crustacea & 1.29 & 0.80 & 0.28 & 1.42 & 0.36 \\
\hline Unident. Crustacea & 12.40 & 7.40 & 21.50 & 14.88 & 14.29 \\
\hline \multicolumn{6}{|l|}{ Mollusca } \\
\hline Gastropoda & 0.31 & 0.00 & 0.00 & 0.00 & 0.00 \\
\hline Bivalvia & 1.80 & 16.47 & 2.18 & 10.55 & 1.51 \\
\hline Ident. Mollusca & 0.04 & 2.71 & 0.24 & 1.40 & 0.00 \\
\hline Echinodermata & 0.00 & 0.00 & 11.14 & 6.45 & 0.00 \\
\hline Teleostei & 5.88 & 24.65 & 4.72 & 1.73 & 0.17 \\
\hline Algae (filamentous) & 9.26 & 3.35 & 1.79 & 1.07 & 6.20 \\
\hline Algae (thallic) & 2.00 & 4.53 & 14.39 & 7.24 & 1.13 \\
\hline Sand & 26.33 & 11.20 & 0.09 & 0.54 & 41.66 \\
\hline Miscellaneous & 5.48 & 396 & 8.92 & 3.36 & 34.58 \\
\hline Levin's index a & 0.31 & 0.29 & 0.31 & 0.30 & 0.09 \\
\hline & 0.41 & 0.25 & 0.31 & 0.30 & 0.06 \\
\hline Spearman & 0.934 & 0.958 & 0.378 & 0.321 & 0.985 \\
\hline
\end{tabular}

found only in the foreguts of $C$. crangon caught in the shallowest water $(0.5$ to $1 \mathrm{~m})$ and not at all in the foreguts of C. maenas. Juvenile Corystes cassivelaunus were found mainly in foreguts of $C$. crangon and $C$. maenas from deeper samples but also occurred in the foreguts of some C. crangon taken at shallower depths.

\section{Predation on fishes}

Occurrence and relative importance of fishes as prey

Fish remains, including otoliths, scales and skeletal remains, were identified in the stomachs of all of the 5 species examined (Tables $5 \& 6$ ). The overall percent- 
age frequency of occurrence ranged from $4.5 \%$ in Pagurus bernhardus to $54.8 \%$ in Carcinus maenas. Fish remains accounted for $24.6 \%$ of the overall volume of the diet in C. maenas and $5.9 \%$ in Crangon crangon, with smaller proportions in Liocarcinus depurator and $P$. bernhardus.

Identity of fishes eaten

Identifiable fish remains included sand eels Ammodytes sp., Gobiidae, pogge Agonus cataphractus, bull-rout Myoxocephalus scorpius and Pleuronectidae. The relative frequency of round fish and flatfish remains in the foreguts varied between sampling dates and between species. In both Crangon crangon and Carcinus maenas the relative percentage frequency of mid-guts with flatfish remains, compared with those with round fish remains, fell between June and August (Fig. 5A, B). In C. crangon this fall in relative proportions resulted from an increase in the percentage frequency of foreguts with round fish remains, while the percentage frequency of foreguts with flatfish remains stayed constant (Fig. 5C). In C. maenas the fall in relative proportions reflected mainly a decrease in the percentage frequency of foreguts with flatfish remains, although the percentage frequency of foreguts with round fish remains also fell slightly (Fig. 5D). In $C$. crangon the percentage frequency of foreguts with unidentifiable fish remains rose between June and August (Fig 5C), while in C. maenas the percentage frequency with unidentifiable fish remains fell (Fig. 5D). In Liocarcinus holsatus, among foreguts with recognizable fish remains, there were more with flatfish than with round fish overall, but the numbers were insufficient to reveal if there was any change between June and August.

Temporal and spatial changes in the proportion of macrocrustaceans with fishes in their diet

The proportion of Crangon crangon that contained fish remains showed significant differences among depths of capture and times of day (Table 8). There was no consistent trend in the differences among depths (Fig. 6A), but the proportion changed consistently with time of sampling with the lowest proportion being found before sunset ( $S S-3$ ) and the highest after sunrise (SR +3 ) (Fig. 6B). Carcinus maenas also showed a consistent temporal trend in the proportion with fish in the foregut although with slightly different timing (Fig. 6D); here the proportion was greatest at MSSSR or at sunrise (SR). The proportion with fish remains increased in August. Both $C$. crangon and $C$. maenas also showed significant tidal effects (Table 8 , significant Cosine effect); in the former the proportion containing fish remains tended to increase at high water, whilst the latter showed the opposite trend, with the proportion lowest at high water. Generally, in $C$. crangon, the proportion with fish remains at all depths was variable and low (0 to $10 \%$ ), while in C. maenas it was consistently high ( 40 to $66.7 \%$ ). Overall, $54.8 \%$ of C. maenas but only $6.02 \%$ of $C$. crangon contained fish remains (Table 5).

Table 8 . Significances associated with probabilities of Wald statistics computed in the CATMOD procedure (see 'Materials and methods') for numbers of foreguts with and without fish remains among all those examined in the common species of crustaceans in catches. For Liocarcinus depurator and Pagurus bernhardus the data were insufficient to allow a complete analysis. Species abbreviations as in Table 4. Significance: $\cdots p<0.001, \cdots 0.001<p<0.01, \cdot 0.01<p<0.05, n s: p>0.05$

\begin{tabular}{lccccccc|}
\hline Source & df & C cra & C mae & L hol & L dep & P ber \\
\hline Depth & 5 & $\cdot$ & ns & ns & & \\
TOD & 4 & $\cdot$ & $\cdot$ & ns & & \\
Date & 2 & $n s$ & $\cdot$ & ns & ns & \\
Cosine (Time relative & 1 & $\cdot$ & $\cdot$ & ns & ns & ns \\
$\quad$ to high water) & & & & & & \\
$\begin{array}{l}\text { Sine (Time relative } \\
\text { to high water) }\end{array}$ & 1 & ns & ns & ns & ns & ns \\
& & & & & & \\
\hline
\end{tabular}




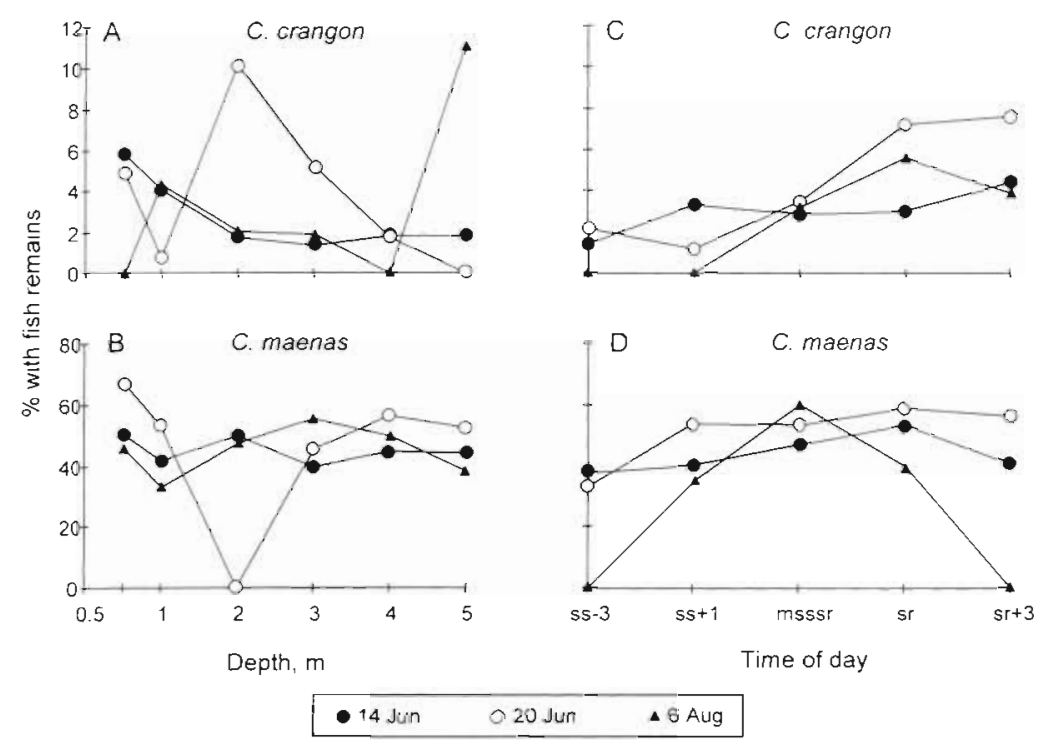

Fig. 6. Variation in the proportion of foreguts containing fish remains for (A, C) Crangon crangon and (B, D) Carcinus maenas. Seasonal variation in the pattern of occurrences of fish remains by $(A, B)$ depth and $(C, D)$ time of day. Abbreviations as in Fig. 1

\section{Temporal and spatial variation in feeding intensity}

Proportion of empty foreguts

The proportion of Crangon crangon with empty foreguts showed significant differences among depths of capture (Table 9) but there was no consistent trend in the differences (Fig. 7 A). The proportion changed both significantly (Table 9) and consistently with Time of Day; the proportion with empty foreguts was greatest in samples taken at $\mathrm{SS}+1$ and declined to a minimum at SR (Fig. 7C). The proportion with empty foreguts declined significantly in August. In Carcinus maenas significant differences among Times of Day showed a sim-

Table 9. Significance associated with probabilities of Wald statistics computed in the CATMOD procedure (see 'Materials and method.s') comparing numbers of empty foreguts and numbers of foreguts with food among all those examined in the common species of crustaceans in catches. For Liocarcinus depurator and Pagurus bernhardus the datd were insufficient to allow a complete analysis. Species abbreviations as in Table 4. Significance: $\cdots p<0.001, \cdots 0.001<p<0.01$, $\cdot 0.01<\mathrm{p}<0.05, \mathrm{~ns}: \mathrm{p}>0.05$

\begin{tabular}{lccccccc|}
\hline Source & df & Ccra & Cmae & L. hol & L dep & Pber \\
\hline Depth & 5 & $\cdots$ & ns & & & \\
TOD & 4 & $\cdots$ & $\cdots$ & ns & ns & \\
Date & 2 & $\cdots$ & ns & $\cdots$ & ns & \\
$\begin{array}{l}\text { Cosine (Time relative } \\
\text { to high water) }\end{array}$ & 1 & ns & ns & $\cdot$ & ns & ns \\
$\begin{array}{l}\text { Sine (Time relative } \\
\text { to high water) }\end{array}$ & 1 & ns & ns & ns & ns & ns \\
& & & & & & \\
\hline
\end{tabular}

ilar trend to C. crangon, but with a slight difference in timing; the proportion with empty foreguts was greatest at SS -3 and lowest at MSSSR (Fig. 7D). Throughout, the proportion with empty foreguts was consistently greater in C. crangon than in C. maenas. In Liocarcinus holsatus, the proportion with empty forguts was greatest at 0.5 and $5 \mathrm{~m}$ depths, i.e. at the extremes of the depth distribution, was lower around the time of high water compared with low water, and increased in August (Table 9, significant Depth, Date and Cosine effects).

\section{Stomach fullness}

Both Crangon crangon and Carcinus maenas generally had significantly fuller foreguts during the hours of darkness (Figs. 8 \& 9, Kruskal-Wallis test, p $=0.01$ and 0.0004 respectively). Differences in the distribution of stomach fullness scores in the other 3 species examined were not significant (Kruskal-Wallis test, $\mathrm{p}=0.48,0.57$ and 0.12 for Liocarcinus holsatus, $L$. depurator and Pagurus bernhardus respectively).

\section{DISCUSSION}

\section{Species composition}

Only 9 species of macrocrustaceans were caught during the study. This compares with a total of 33 species of fishes caught during the same study (Gibson \& Robb 1996, Gibson et al. 1996). In a more extensive 4 yr study in the same area, 15 species of macrocrustaceans were caught, but several of these were of only rare occurrence or occurred in only 1 of the 4 years studied (Gibson et al. 1993). As a consequence of the low numbers of species overall, the temporal and spatial changes seen in species composition were small compared with those of the fishes (Gibson et al. 1996), but were nonetheless significant. Changes in percentage similarity between dates in the species composition of catches were similar for both macrocrustaceans and fishes, but were more marked in the latter (Table 3).

\section{Depth distribution and temporal changes in depth distribution and abundance}

There was a clear positive relationship between depth and species richness, while the number of indi- 
viduals caught showed a negative relationship with depth. The dominance in numbers of Crangon crangon, and their decreasing abundance with depth below $1 \mathrm{~m}$, is mainly responsible for the decrease in total numbers found at greater depths. These relationships are similar to those found for the fish community from the same samples (Gibson et al. 1996) which also show an increase in species richness with depth, and a decrease in numbers of individuals, mainly reflecting the dominance of 1 species (0-group plaice Pleuronectes platessa) in shallow depths. At $5 \mathrm{~m}$ depth, fish numbers again increased, mainly because of the predominance of gadoids. There was no comparable increase in macrocrustacean numbers since, although some species such as Pagurus bernhardus are characteristically present mainly at this depth, they do not appear in large numbers.

Gibson et al. (1996), for the fish populations present in the area, distinguish 4 basic patterns of movement of individual species into and out of shallow water that affect the overall patterns of distribution on dif-
C. crangon

20 Jun
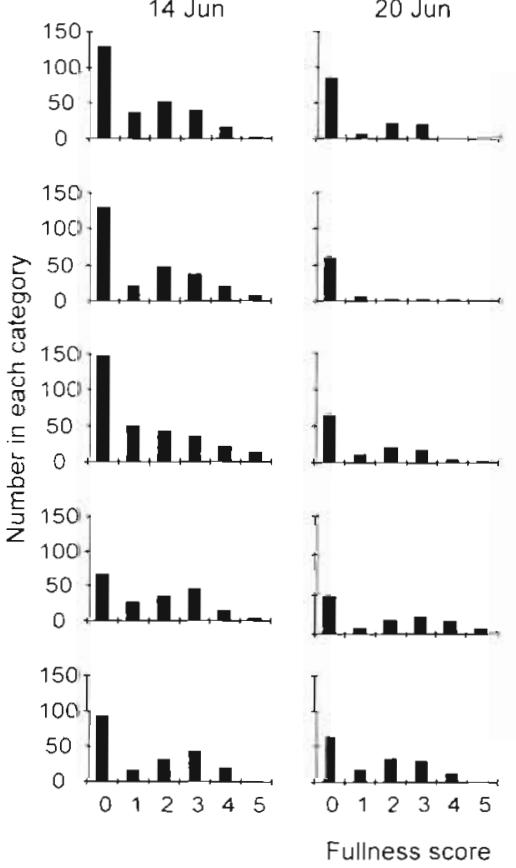

Fig. 8. Variation in the distribution of foregut fullness scores over the 5 sampling periods for each collection date for Crangon crangon

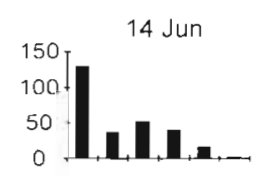

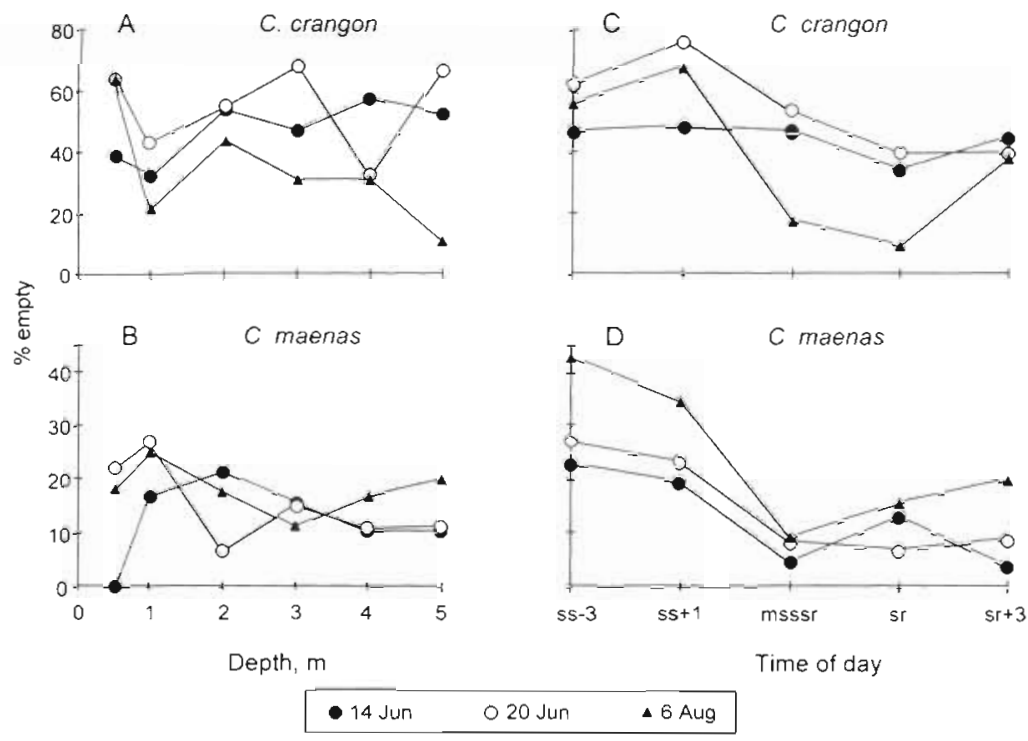

Fig. 7. Variation in the proportion of empty foreguts for $(A, C)$ Crangon crangon and (B, D) Carcinus maenas. Seasonal variation in the pattern of occurrence of empty foreguts by $(A, B)$ depth and $(C, D)$ time of day. Abbreviations as in Fig. 1 ferent time-scales, i.e. tidal movements, diel movements, longer term movements, and no movement. Similar patterns affect the macrocrustacean populations.

\section{C. maenas}
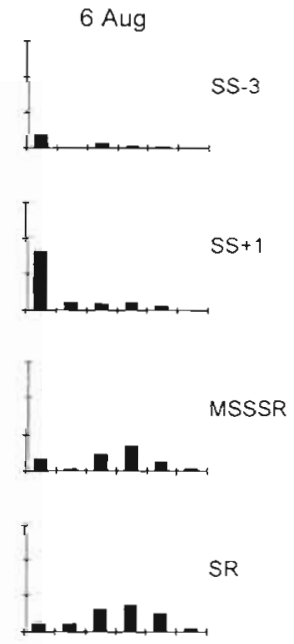

$\mathrm{SR}+3$

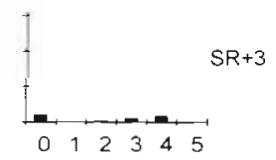

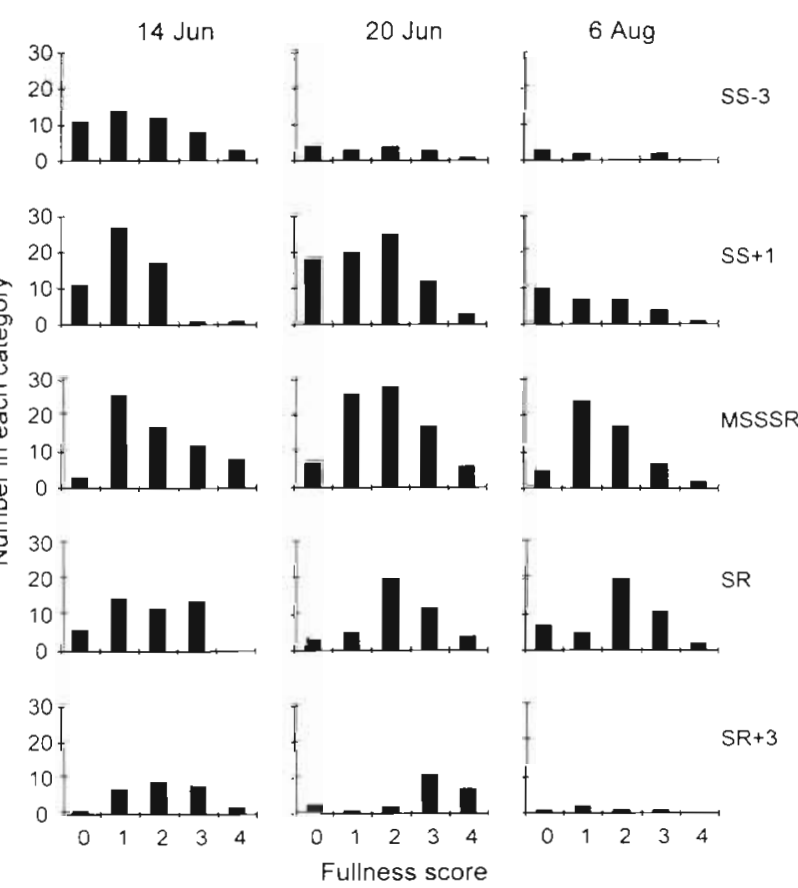

S-3

Fig. 9. Variation in the distribution of foregut fullness scores over the 5 sampling periods for each collection date for Carcinus maenas. No foreguts were assigned a fullness score of 5 


\section{Tidal movements}

Of the macrocrustacean species caught, Crangon crangon and Carcinus maenas are known to show movements into the intertidal zone at high water (Al Adhub \& Naylor 1975, Janssen \& Kuipers 1980, Dare \& Edwards 1981, Hunter \& Naylor 1993, Burrows et al. 1994) and these movements may be in part responsible for the significant tidal effect on catches of these 2 species recorded here. They resemble the migration pattern shown by juvenile flatfishes, particularly 0-group plaice, in the same area, although it is not clear whether the macrocrustacean movements are as directed as those of some fishes.

\section{Diel movements}

The greater numbers of individuals and species found in night catches suggest an onshore migration at dusk followed by an offshore migration at dawn, similar to that shown by gadoid fishes in the same area (Gibson et al. 1996). However, it is not possible to entirely distiguish between diel vertical movements and diel variations in activity that do not involve vertical migration. Crangon crangon and Carcinus maenas have both been shown experimentally to be more active nocturnally (Naylor 1958, Kitching et al. 1959, Hagerman 1970, Dyer \& Uglow 1978, van Donk \& de Wilde 1981), and, in underwater television observations in the same area as this study, both species were seen more at night than during the daylight (Burrows et al. 1994). In contrast, on a microtidal beach in Sweden, C. crangon were mostly active during the day while $C$. maenas were nocturnally active, with neither species showing migration (Gibson et al. 1998). Abello et al. (1991) found that Liocarcinus depurator were most active at night, but, contrary to the present observations, L. holsatus were most active during the day. A second, and perhaps more likely, explanation for the smaller catches of most crabs during the day is that many macrocrustacean individuals are buried and inactive during this period. Underwater television recordings made in the nearby Dunstaffnage Bay (A. D. Ansell unpubl. obs.) have shown individual $C$. maenas burrowing into the substratum at dawn and remaining buried within the field of view of the camera for periods of up to $14 \mathrm{~h}$ in summer. Buried C. crangon show a much reduced tendency to respond to mechanical stimulation by tail flipping compared to individuals on the surface (K. Smith unpubl. obs). Although the trawl used in this study had tickler chains, it is likely that buried crabs and shrimps show reduced sensitivity to mechanical stimulus, resulting in reduced catching efficiency of the trawl, and hence lower catches by day than by night.
Longer term movements

All the main species decreased in abundance between June and August, which parallels changes in abundance of many of the fish species in the same area (Gibson et al. 1996), and results from similar processes of recruitment, mortality and onshore-offshore migration. It is perhaps surprising that this effect was so marked for the macrocrustaceans; in an earlier study over $4 \mathrm{yr}$, macrocrustacean abundance reached its peak in. July/August, somewhat later than that of the fish populations. Both Crangon crangon and Carcinus maenas are known to show similar seasonal migration elsewhere (Lloyd \& Yonge 1947, Naylor 1962, Boddeke 1976, Klein Breteler 1976. Henderson et al. 1990).

\section{Diet of epibenthic macrocrustaceans}

The analysis of the contents of the foreguts of the 5 macrocrustacean species examined indicates that all are omnivorous feeders with the possible exception of Pagurus bernhardus, for which Levins' niche breadth index was relatively low. Otherwise, there was little or no indication of dietary specialisation, and the diets showed a high degree of overlap. Measures such as Levins' index and percentage overlap between diets are of questionable utility, however, for such species for which only a relatively small proportion of the gut contents are identifiable beyond the highest taxonomic categories. Both benthic and epibenthic invertebrates and fish occur in the diet, and it is likely that the remains found represent the results of both predation and scavenging. In these respects, the compositions of the diets found here resemble those found elsewhere for these and other related species of shrimp and portunid crabs (Ebling et al. 1964, Muntz et al. 1965, Crothers 1968, Ropes 1968, Hill 1976, González-Gurriarán 1978, EIner 1981, Paul 1981, Williams 1982, Pihl \& Rosenberg 1984, Pihl 1985, Choy 1986, Matsui et al. 1986, Abello \& Cartes 1987, Wear \& Haddon 1987, Hall et al. 1990, Norman \& Jones 1992). Factors masking potential differences between the species include the possibility that some items found represent the contents of the guts of prey ('secondary predation') and the potentially long retention times of remains such as the chitinous skeletons of Crustacea, calcified fish otoliths and bones, and molluscan shells or opercula (Hill 1976). Long retention times for some items will also tend to mask any short-term, tidal or diel changes in diet.

Algae occurred in the diets of all 5 species examined and herbivory is now a well-documented feature of the diet of macrocrustaceans, especially portunid crabs (González-Gurriarán 1978, Choy 1986, Raffaelli et al. 
1989, Norman \& Jones 1992). Norman \& Jones (1990) showed that Necora puber can digest laminarin, the principal carbohydrate in brown algae. The habit is not restricted to portunids; algae also contribute in varying degrees to the diet of various spider crabs (Hartnoll 1963) and mud crabs Scylla serrata (Hill 1976) among others. Considerable amounts of sand were also found in the forguts, especially in Crangon crangon and Pagurus bernhardus, suggesting that there is a contribution of non-selective microphagy to the diet.

\section{Cyclic variations in feeding intensity of macrocrustaceans}

The present study has provided evidence of cyclic variations in feeding intensity of macrocrustaceans that reflect the rhythms in their locomotory activities and migrations. Similar cycles have been reported elsewhere. For Crangon crangon, Pihl \& Rosenberg (1984) found the lowest proportions of empty stomachs around dawn and dusk, indicating increased nocturnal or crepuscular feeding. Del Norte Campos \& Temming (1994) also found a feeding peak for C. crangon at dawn in the northern Wadden Sea. Freire et al. (1991) found 'higher repletion values' for Liocarcinus depurator from night samples than from those collected during daylight in areas of the Ria de Arosa, NW Spain, not affected by the raft culture of mussels. Evans (1983) carried out $24 \mathrm{~h}$ sampling in August and October in a shallow soft bottom community on the Swedish west coast. He found no consistent variation in stomach weight of $C$. crangon as a percentage of total weight, but the 2 examples he illustrates (his part IV, Table 6) both show the highest values during darkness (ca 03:00 h).

\section{Impact of macrocrustacean predation on fish populations}

The area studied here, in common with other shallow sandy bays around the Scottish coast (Edwards \& Steele 1968, Poxton et al. 1983, Ansell \& Gibson 1990), is a fish nursery area. In summer, the demersal fish community is dominated by juvenile flatfishes, particularly plaice Pleuronectes platessa and dabs Limanda limanda, and gobies Pomatoschistus minutus. Sand eels Ammodytes tobianus and juvenile herring Clupea harengus and sprat Sprattus sprattus dominate the pelagic fish community (Gibson et al. 1993). Abundant recruitment of juveniles to the fish population in spring and early summer is followed by a rapid depletion of numbers. Such depletion, which is a common feature of the seasonal development of fish populations on nursery grounds on European coasts, has been attributed to predation (van der Veer et al. 1991, Beverton \& Iles 1992) but until recently the causes had rarely been positively identified. All 5 of the macrocrustacean species examined in this study, however, contained fish remains, indicating that predation by epibenthic macrocrustaceans could contribute to fish mortality. Nevertheless, it is impossible to determine how far the fish remains seen in the foreguts derive from active predation of live fishes by the macrocrustaceans or how far they result from scavenging of dead or moribund material. The best evidence that active predation is involved comes from laboratory observations (Crothers 1968, van der Veer \& Bergman 1987, Ansell \& Gibson 1993, Gibson et al. 1995, Witting \& Able 1995) that have shown that Crangon spp. (including $C$. crangon), Carcinus maenas, and Liocarcinus holsatus are all adept at capturing and ingesting small, healthy flatfishes, using mainly ambush techniques, although the conditions in such experiments favour the success of the predator.

The proportion of Crangon crangon foreguts that contained fish remains in the present study compares closely with the results of a similar study in the Dutch Wadden Sea (van der Veer \& Bergman 1987) where $5 \%$ of shrimp were found to contain fish, particularly juvenile plaice. In other areas, fish have also been reported as part of the diet of crabs, in some cases making a major contribution. For Liocarcinus depurator from the Catalan coast, Spain, Abello \& Cartes (1987) found the remains of a number of round fish species, accounting for up to $25 \%$ of the diet depending on time of year, while Freire et al. (1991) found mainly goby remains in the same species in the Ria de Arosa also in up to $25 \%$ of individuals. In L. holsatus, Choy (1986) found remains which she attributed to gobies and pleuronectids in $22 \%$ of stomachs, although fish remains accounted for only up to $10 \%$ by volume of the contents. Up to $10.9 \%$ of stomachs of Necora puber from deeper circatidal areas of the South Devon coast, United Kingdom, also contained fish remains accounting for up to $9.8 \%$ of the volume (Norman \& Jones 1992). Carcinus maenas has been recorded as having various fish in its diet (Perkins 1967), although Ropes (1968) recorded only a few crabs $(\sim 5 \%)$ with fish remains, usually bones, which contrasts with the high percentages found in this study. In other areas foregut contents of $C$. crangon and $C$. maenas have been examined without finding fish remains (Evans 1983, Raffaelli et al. 1989). We could find no records of Pagurus bernhardus as an active fish predator. Since all the macrocrustaceans examined are omnivores it is possible that an abundance of other prey may reduce the numbers of fishes taken, effectively providing them protection. 
Although the present data do not allow the estimation of the absolute predation rate by macrocrustaceans on fishes, and particularly juvenile flatfishes, in this nursery ground, it is possible to assess the relative potential predation impact of shrimps and crabs respectively. During June, Crangon crangon were some 20 times more abundant than Carcinus maenas and other crabs in water depths $<5 \mathrm{~m}$ on Tralee Beach. This greater abundance, however, is more than balanced by 2 factors: (1) fish remains were found in the foreguts of a much higher proportion of crabs than of shrimps (50 vs $5 \%$ ), and (2) crabs have a much greater potential intake of prey than shrimps by virtue of their greater size and consequently much greater foregut volume (15 to 20 times, C. A. Comely \& A. D. Ansell unpubl. data). Combining these factors suggests that the impact of crab predation may have been some 30 times greater than that of shrimps in this area in June. A similar comparison for August, by which time the numbers of $C$. crangon had greatly reduced, suggests that crab predation may then have been relatively even more important. The different distribution of shrimp and crabs, the former in shallower and the latter in deeper water, does imply, however, that their predation impact may affect different components of the overall fish community. 0-group plaice, for example, are most abundant in shallow water, maintaining their distribution by tidal migration, while 0-group dabs remain predominantly in the area below low water mark at all states of the tide (Gibson 1973). Thus, spatial and temporal overlaps between the fish and macrocrustacean populations would appear to favour predation by shrimps on plaice and by crabs on dabs. Further studies are needed to determine if this is indeed the case.

Macrocrustaceans are not the only predators on juvenile fishes in Tralee Bay or other similar nursery grounds. Juvenile fishes are frequently preyed on by larger fishes (see e.g. Nellen 1986 for examples). Gadoid fishes are commonly cited as predators of juvenile plaice (Riley \& Corlett 1966, Edwards \& Steele 1968, Pihl 1982) and Lockwood (1980) suggested that fish predators might be responsible for density-dependent mortality of 0-group plaice. Ellis \& Gibson (1995) found that $5.5 \%$ of 0 -group cod $(n=344), 0.8 \%$ of 0 -group whiting $(\mathrm{n}=593)$ and $29 \%$ of 1 -group poorcod $(n=7)$ caught at Tralee contained flatfish remains, of which $84 \%$ were dabs, $2 \%$ flounder and the rest unidentifiable. Gibson \& Robb (1996) have recently shown, based on analysis of the stomach contents of the fishes caught during the present study, that predation by larger fishes is a major cause of mortality for the populations of juvenile fishes on Tralee beach. In June, fish predation was concentrated on the most numerous species (0-group plaice) but with the decline in num- bers and increase in size of this species, the fish predators had changed their diet in August to feed principally on small sand eels. The decline found here between June and August in the proportion of macrocrustacean foreguts that contained flatfish remains compared with those that contained round fish remains suggests that, like fish predation, macrocrustacean predation on fishes was concentrated on the most numerous species available within the vulnerable size range. Like the macrocrustaceans, at least one of these larger fish predators (cod Gadus morhua) is active mainly at night, when they migrate into shallow water (Pihl 1982, Keats \& Steele 1992, Burrows et al. 1994, Gibson \& Robb 1996, Gibson et al. 1996, 1998). Thus, a considerable component of the predation impact on juvenile fish populations in areas like Tralee Bay appears to take place between dusk and dawn.

Acknowledgements. We greatly appreciate the help given by Robin Gibson, Maggie Watson, John Fitzgerald, Odd-Axel Bergstad and lan Drummond, skipper of the RV 'Seol Mara', in the fieldwork associated with this study, and we thank Mike Burrows for valuable advice and help with the statistical analysis of the results.

\section{LITERATURE CITED}

Abello P, Cartes J (1987) Observaciones sobre la alimentacion de Liocarcinus depurator (L.) (Brachyura: Portunidae) en el Mar Catalan. Invest Pesq 51(suppI 1):413-419

Abello P, Reid DG, Naylor E (1991) Comparative locomotor activity patterns in the portunid crabs Liocarcinus holsatus and L. depurator. J Mar Biol Assoc UK 71:1-10

Al-Adhub AHY, Naylor E (1975) Emergence rhythms and tidal migrations in the brown shrimp Crangon crangon (L.). J Mar Biol Assoc UK 55:801-810

Ansell AD, Gibson RN (1990) Patterns of feeding and movement of juvenile flatfishes on an open sandy beach. In: Barnes M, Gibson RN (eds) Trophic relationships in the marine environment. Aberdeen University Press, Aberdeen, p 191-207

Ansell AD, Gibson RN (1993) The effect of sand and light on predation of juvenile plaice (Pleuronectes platessa) by fishes and crustaceans. J Fish Biol 43:837-845

Beverton RJH, Iles TC (1992) Mortality rates of 0-group plaice (Pleuronectes platessa L.), dab (Limanda limanda L.) and turbot (Scophthalmus maximus) in European waters. II Comparison of mortality rates and construction of life table for 0-group plaice. Neth J Sea Res 29:49-59

Boddeke R (1976) The seasonal migration of the brown shrimp Crangon crangon. Neth J Sea Res 10:103-130

Brown AC, McLachlan A (1991) Ecology of sandy shores. Elsevier, Amsterdam

Burrows MT, Gibson RN, Robb L, Comely CA (1994) Temporal patterns of movement in juvenile flatfishes and their predators: underwater television observations. J Exp Mar Biol Ecol 177:251-268

Choy SC (1986) Natural diet and feeding habits of the crabs Liocarcinus puber and L. holsatus (Decapoda, Brachyura, Portunidae). Mar Ecol Prog Ser 31:87-99

Crothers JH (1968) The biology of the shore crab Carcinus maenas (L.) 2. The life of the adult crab. Field Stud 2:579-614 
Dare PJ, Edwards DB (1981) Underwater television observations on the intertidal movements of shore crabs, Carcinus maenas, across a mudflat. J Mar Biol Assoc UK 61:107-116

Del Norte Campos AGC. Temming A (1994) Daily activity and rations in gobies and brown shrimp in the northern Wadden Sea. Mar Ecol Prog Ser 115:41-53

Dyer MF, Uglow RF (1978) Heart and scaphognathite beat behaviour in laboratory-held Crangon crangon (L.). J Exp Mar Biol Ecol 32:209-218

Ebling FJ, Kitching JA, Muntz L, Taylor CM (1964) The ecology of Lough Ine. XIII. Experimental observations of the destruction of Mytilus edulis and Nucella lapillus by crabs. $\mathrm{J}$ Anim Ecol 33:73-82

Edwards RRC, Steele JH (1968) The ecology of 0-group plaice and common dabs at Loch Ewe. I. Population and food. J Exp Mar Biol Ecol 2:215-238

Ellis T, Gibson RN (1995) Size-selective predation of 0-group flatfishes on a Scottish coastal nursery ground. Mar Ecol Prog Ser 127:27-37

Elner RW (1981) Diet of the green crab Carcinus maenas (L.) From Port Hebert, south-western Nova Scotia. J Shellfish Res 1:89-94

Evans S (1983) Epibenthic communities on shallow soft bottoms in Gullmar Fjord, Sweden. Doctoral thesis, Uppsala University

Freire J, Fernandez L, González-Gurriarán E (1991) Diel feeding pattern of Liocarcinus depurator (Brachyura: Portunidae) in the Ria de Arosa (Galicia, N.W. Spain). Ophelia 33:165-177

Gibson RN (1973) The intertidal movements and distribution of young fish on a sandy beach with special reference to the plaice (Pleuronectes platessa). J Exp Mar Biol Ecol 12: $79-102$

Gibson RN, Ansell AD, Robb L (1993) Seasonal and annual variations in abundance and species composition of fish and macrocrustacean communities on a Scottish sandy beach. Mar Ecol Prog Ser 98:89-105

Gibson RN, Pihl L, Burrows MT, Modlin J, Wennhage $H$, Nickell LA (1998) Diel movements of juvenile plaice Pleuronectes platessa in relation to predators, competitors, food availability and abiotic factors on a microtidal nursery ground. Mar Ecol Prog Ser 165:145-159

Gibson RN, Robb L (1996) Piscine predation on juvenile fishes on a Scottish sandy beach. J Fish Biol 49:120-138

Gibson RN, Robb L, Burrows MT, Ansell AD (1996) Tidal, diel and longer term changes in the distribution of fishes on a Scottish sandy beach. Mar Ecol Prog Ser 130:1-17

Gibson RN, Yin MC, Robb L (1995) The behavioural basis of predator-prey size relationships between shrimp (Crangon crangon) and juvenile plaice (Pleuronectes platessa) J Mar Biol Assoc UK 75:337-349

González-Gurriarán E (1978) Introducción al estudio de la alimentación en la necora, Macropipus puber (L.) (Decapoda, Brachyura) en la Ria de Arosa (Galicia-España). Boln Inst Esp Oceanogr 4:81-93

Gregory SF (1988) An investigation of the invertebrate macrofauna of a sandy beach near Oban, Argyll, with specific study of mouthpart components of Bathyporeia pilosa Lindström and B. pelagica (Bate) (Amphipoda: Haustoriidae). BSc (Hons) thesis, University of Stirling

Hagerman L. (1970) Locomotory activity patterns of Crangon vulgaris (Fabricius) (Crustacea, Natantia). Ophelia 8:255-256

Hall SJ, Raffaelli D, Robertson MR, Basford DJ (1990) The role of the predatory crab, Liocarcinus depurator, in a marine food web. J Anim Ecol 59:421-438

Hartnoll RG (1963) The biology of Manx spider crabs. Proc Zool Soc Lond 141:423-496
Hayward PJ, Ryland JS (eds) (1990) The marine fauna of the British Isles and north-west Europe. Vol 1 Introduction and protozoans to arthropods. Clarendon Press, Oxford

Henderson PA, Seaby R, Marsh SJ (1990) The population zoogeography of the common shrimp (Crangon crangon) in British waters. J Mar Biol Assoc UK 70:89-97

Hill BJ (1976) Natural food, foregut clearance rate and activity of the crab Scylla serrata. Mar Biol 34:109-116

Hunter E, Naylor E (1993) Intertidal migration by the shore crab Carcinus maenas. Mar Ecol Prog Ser 101:131-138

Janssen GM, Kuipers BR (1980) On tidal migration in the shrimp Crangon crangon. Neth J Sea Res 14:339-348

Keats DW, Steele DH (1992) Diurnal feeding of juvenile cod (Gadus morhua) which migrate into shallow water at night in eastern Newfoundland. I Northwest Atl Fish Sci 13 $7-14$

Kitching JA, Sloane JF, Ebling FJ (1959) The ecology of Loch Ine VIlI. Mussels and their predators. J Anim Ecol 28 $331-341$

Klein Breteler WCM (1976) Migration of the shore crab, Carcinus maenas, in the Dutch Wadden Sea. Neth J Sea Res 10:338-353

Krebs CJ (1989) Ecological methodology. Harper \& Row, New York

Kuipers B (1975) On the efficiency of a two-metre beam trawl for juvenile plaice (Pleuronectes platessa). Neth J Sea Res 9:69-85

Lloyd AJ, Yonge CM (1947) The biology of Crangon vulgaris L. in the Bristol Channel and Severn Estuary. J Mar Biol Assoc UK 26:626-661

Lockwood SJ (1974) The settlement, distribution and movements of 0-group plaice Pleuronectes platessa (L.) in Filey Bay, Yorkshire. J Fish Biol 6:465-477

Lockwood SJ (1980) Density-dependent mortality in 0-group plaice (Pleuronectes platessa L.) populations. J Cons Int Explor Mer 39:148-153

Matsui S, Hagiwara Y, Tou H, Tsukahara H (1986) Study on the feeding habits of the Japanese blue crab, Portunus trituberculatus (Miers). Sci Bull Fac Agric Kyushu Univ 40: $175-181$

Muntz L, Ebling FJ, Kitching JA (1965) The ecology of Lough Ine. XIV. Predatory activity of large crabs. J Anim Ecol 34: $315-329$

Naylor E (1958) Tidal and diurnal rhythms of locomotory activity in Carcinus maenas (L.). J Exp Biol 35:602-610

Naylor E (1962) Seasonal changes in a population of Carcinus maenas (L.) in the littoral zone. J Anim Ecol 31:601-609

Nellen W (1986) A hypothesis on the fecundity of bony fish. Meeresforsch 31:75-89

Norman CP, Jones MB (1990) Utilization of brown algae in the diet of the velvet swimming crab Liocarcinus puber (Brachyura: Portunidae). In: Barnes M. Gibson RN (eds) Trophic relationships in the marine environment. Aberdeen University Press, Aberdeen, p 491-502

Norman CP, Jones MB (1992) Influence of depth, season and moult stage on the diet of the velvet swimming $\mathrm{crab} \mathrm{NeC-}$ ora puber (Brachyura, Portunidae). Estuar Coast Shelf Sci $34: 71-83$

Paul RKG (1981) Natural diet, feeding and predatory activity of the crabs Callinectes arcuatus and C. toxotes (Decapoda, Brachyura, Portunidae). Mar Ecol Prog Ser 6:91-99

Perkins EJ (1967) Some aspects of the biology of Carcinus maenas (L.). Trans Dumfries Galloway Nat Hist Antiquar Soc Ser $344: 47-56$

Pihl L (1982) Food intake of young cod and flounder in a shallow bay on the Swedish west coast. Neth J Sea Res 15: 419-432 
Pihl L (1985) Food selection and consumption of mobile epibenthic fauna in shallow marine areas. Mar Ecol Prog Ser 22:169-179

Pikl L, Rosenberg R (1984) Food selection and consumption of the shrimp Crangon crangon in some shallow marine areas in western Sweden. Mar Ecol Prog Ser 15: $159-168$

Poxton MG, Eleftheriou A, McIntyre AD (1983) The food and growth of 0-group flatfish on nursery grounds in the Clyde Sea area. Estuar Coast Shelf Sci 17:319-337

Raffaelli D, Conacher A, McLachlan H, Emes C (1989) The role of epibenthic crustacean predators in an estuarine food web. Estuar Coast Shelf Sci 28:149-160

Riley JD, Corlett J (1966) The numbers of 0-group plaice in Port Erin Bay 1964-66. Rep Mar Biol Stn Port Erin 78: $51-56$

Rogers SI, Lockwood SJ (1989) Observations on the capture efficiency of a two-metre beam trawl for juvenile flatfish. Neth J Sea Res 23:347-352

Ropes JW (1968) The feeding habits of the green crab Carcinus maenas (L.). Fish Bull US 67:183-203

SAS Institute Inc (1990) SAS procedures guide, Version 6, 3rd edn. SAS Institute Inc, Cary, NC

van der Veer HW, Bergman MJN (1987) Predation by crustaceans on a newly settled 0-group plaice Pleuronectes

Editorial responsibility: Otto Kinne (Editor),

Oldendorf/Luhe, Germany platessa population in the western Wadden Sea. Mar Ecol Prog Ser 35:203-215

van der Veer HW, Bergman MJN, Dapper R, Witte JIJ (1991) Population dynamics of an intertidal 0-group flounder Platichthys flesus population in the western Dutch Wadden Sea. Mar Ecol Prog Ser 73:141-148

van Donk E, de Wilde PAWJ (1981) Oxygen consumption and motile activity of the brown shrimp Crangon crangon related to temperature and body size. Neth J Sea Res 15: $54-64$

Wear RG, Haddon M (1987) Natural diet of the crab Ovalipes catharus (Crustacea, Portunidae) around central and northern New Zealand. Mar Ecol Prog Ser 35:39-49

Wennhage H, Gibson RN, Robb L (1997) The use of drop traps to estimate the efficiency of two beam trawls commonly used for sampling juvenile flatfishes. J Fish Biol 51: 441-445

Williams MJ (1982) Natural food and feeding in the commercial sand crab Portunus pelagicus Linnaeus, 1766 (Crustacea: Decapoda: Portunidae) in Moreton Bay, Queensland. J Exp Mar Biol Ecol 59:165-176

Witting DA, Able KW (1995) Predation by sevenspine bay shrimp Crangon septemspinosa on winter flounder Pleuronectes americanus during settlement: laboratory observations. Mar Ecol Prog Ser 1.23:23-31

Submitted: May 22, 1998; Accepted: August 27, 1998

Proofs received from author(s): December 16, 1998 